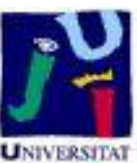

Título artículo / Títol article: Feasible mitigation actions in developing countries

Autores / Autors

Jakob, Michael ; Steckel, Jan Christoph ; Lay, Jann ; Grunewald, Nicole ; Martínez Zarzoso, Inmaculada ; Renner, Sebastian ; Edenhofer, Ottmar

Revista:

Nature Climate Change

Versión / Versió:

Pre-print

Cita bibliográfica / Cita

JAKOB, Michael, et al. Feasible mitigation actions bibliogràfica (ISO 690): in developing countries. Nature Climate Change, 2014, vol. 4, no 11, p. 961-968.

url Repositori UJI: 


\title{
Feasible Mitigation Actions in Developing Countries
}

\author{
Michael Jakob ${ }^{a, b}$, Jan Steckel ${ }^{a, b, c}$, Stefan Klasen ${ }^{d}$, Jann Lay ${ }^{\text {de }}$, Ottmar \\ Edenhofer $^{\mathrm{a}, \mathrm{b}, \mathrm{c}}$, Nicole Grunewald ${ }^{\mathrm{d}}$, Sebastian Renner ${ }^{\mathrm{e}}$, Inmaculada Martínez- \\ Zarzoso $^{\mathrm{d}}$
}

\begin{abstract}
(a) Potsdam Institute for Climate Impact Research PO Box 601203, 14412 Potsdam, Germany
(b) Mercator Research Institute on Global Commons and Climate Change (MCC), Torgauer Str. 12-15, 10829 Berlin

(c) Technical University of Berlin, Department "Economics of Climate Change", Strasse des 17.Juni 145, 10623 Berlin

(d) Georg August Universität Göttingen, Platz der Göttinger Sieben 3, 37073 Göttingen

(e) GIGA German Institute of Global and Area Studies, Hamburg
\end{abstract}

\begin{abstract}
'Preventing dangerous anthropogenic climate change' (UNFCCC 1992) will only be feasible with substantial emission reductions below the business-as-usual case in developing countries. Because of the central role of energy for economic development, reducing emissions in developing countries without undermining their development goals requires a fundamental structural break of the historical correlation between economic growth and GHG emissions. While possible in theory, such a transformation of the global energy system would impose considerable costs on developing countries. Even if these costs were fully covered by industrialized countries, mitigation measures could still be unattractive to developing countries due to a possible 'climate rent curse' through which financial inflows negatively affect recipients' economic performance. Mitigation measures could further meet resistance because of adverse distributional impacts and political economy reasons. Hence, we caution against overly optimistic expectations regarding the opportunities to drastically re-orient development paths towards low-carbon growth. Instead, we suggest that mitigation efforts in developing countries should focus on 'feasible mitigation actions' that seek to maximize mitigation as a positive co-benefit of policies with different objectives.
\end{abstract}




\section{Introduction}

Today's developed countries account for the largest share of global greenhouse gas (GHG) emissions accumulated in the atmosphere. However, recent years have witnessed a rapid increase in developing countries' emissions, most prominently in China, which has not only become the world's largest emitter in 2006, but whose per-capita emissions are now already close to the EU average (7.2t vs. $7.5 t$ of energy related $\mathrm{CO}_{2}$ emissions in 2011, respectively, Olivier et al. 2012). If other developing countries follow China's carbon-intensive growth pattern, ambitious climate stabilization targets - such as the $2^{\circ} \mathrm{C}$ target agreed by the world community (Jaeger and Jaeger 2011) - are likely to become infeasible even if industrialized countries were to drastically reduce their emissions (IEA 2011). For this reason, 'preventing dangerous anthropogenic climate change' (UNFCCC 1992) without undermining poor countries' growth prospects requires a fundamental structural break of the historical correlation between economic growth and GHG emissions. As will be argued in this article, such a transition towards 'low-carbon development' (World Bank 2010) - while possible in theory - is fraught with considerable problems in practice due to the central role that fossil fuels have played and continue to play for economic development. Furthermore, even if the additional costs of lowcarbon technologies (compared to conventional fossil energy sources) were in theory fully covered by industrialized countries, mitigation measures could still be unattractive for both recipient and donor countries due to a possible 'climate rent curse' through which financial inflows negatively affect recipients' economic performance. Hence, we caution against overly optimistic expectations regarding the opportunities to drastically re-orient development paths towards low-carbon growth. Instead, we suggest that mitigation efforts in developing countries should focus on 'feasible mitigation actions' that seek to maximize mitigation as a positive co-benefit of policies with different objectives.

\section{Economic Growth, Income Distribution, Energy Use, and Carbon Emissions}

Socio-economic development in the past has been closely correlated to energy use (Grübler, 2008; Schäfer, 2005). As fossil fuels have traditionally constituted the major source of energy, there is also a close correlation between human development and GHG emissions (Costa et al. 2011). No country has managed to achieve high levels of economic development without having crossed a threshold in final energy consumption of approximately 40 GJ / capita (Steinberger and Roberts 2010; Steckel et al. 2013). Only a fourth of these energy needs can be explained by energy needed for covering subsistence needs like cooking or heating (e.g. Pereira et al. 2011); an important part of the threshold can be explained by energy needed e.g. to build up infrastructure stocks (Steckel et al., 2013).

Developing countries, in particular China, have shown particularly high growth of GHG emissions. For China, but also for other newly industrializing countries, economic growth can clearly be identified to be the main driver of rising $\mathrm{CO} 2$ emissions (Steckel et al. 2011), in particularfor the 2000s. Even though per capita emissions still remain below the OECD average they are - at least in the case of China - catching up fast. ${ }^{1}$ This trend is reinforced by a global "renaissance" of coal that leads to an

\footnotetext{
${ }^{1}$ Due to international trade, those emissions are to some extent embedded in goods that are finally consumed in developed countries (Davis and Caldeira 2010; Peters et al. 2011). However, observed flows of emission
} 
increasing carbonization of the global energy system (Steckel et al., 2011). These trends in economic development, energy use, and carbon emissions in developing countries suggest that they are replicating the pattern observed in the past in today's rich countries - albeit at an accelerated pace (Jakob et al. 2012b). This is illustrated in Figure 1, which shows per-capita $\mathrm{CO}_{2}$ emissions against percapita GDP. It is remarkable that this relationship is very similar for most countries except for some notable outliers, in particular the US with persistently higher per capita emissions than other countries at comparable incomes. For instance, China's current per-capita emissions are very close to those of Korea or Japan at this income level.

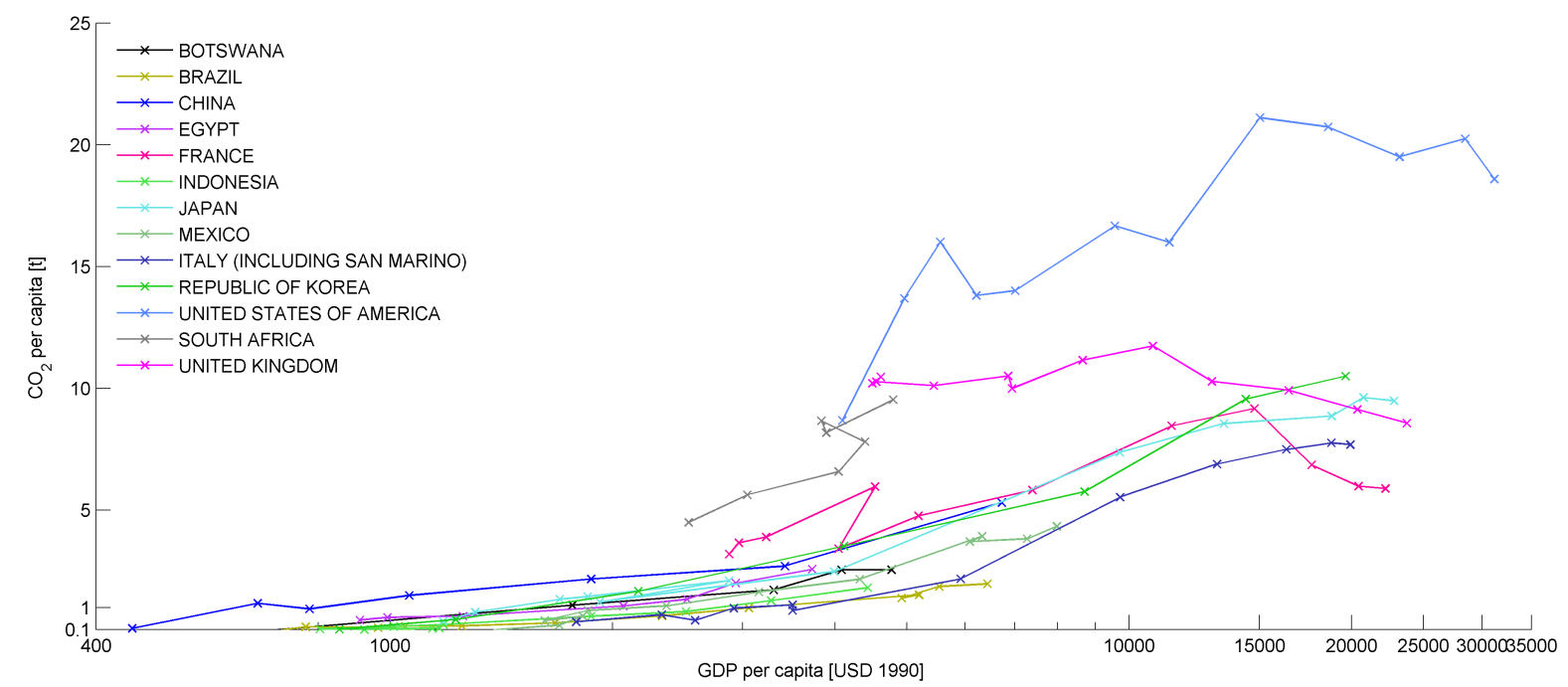

Figure 1: CO2 per capita (CDIAC 2013) over GDP per capita (in 1990 int'I USD, Maddison 2010) for selected countries from 1900 - 2008 for 10 year intervals (when available).

Interestingly, similar patterns can also be found in studies investigating the carbon footprint of households at the micro level for selected developing countries. In other words, an Indonesian household with the income of the average European household exhibits a carbon footprint similar to that of the average European. Specifically, analyses for India, Indonesia and the Philippines show that richer households in these countries have considerably higher carbon footprints than poorer ones. (Grunewald et al., 2012a; Serino, 2012; Irfany, 2013). Figure 2 shows that for these three countries the relationship between income and $\mathrm{CO}_{2}$ emissions in a cross-section of households rather closely matches the relationship between GDP and emissions over time on the macro-economic level. This suggests that income is the most important driver of variations of emissions over time and between households. The figure also illustrates the great extent of inequality of incomes in these countries for example, the mean income of Indonesian households in the highest income quintile is about 8 times the income of those in the lowest quintile. The slightly concave shape of these curves suggests that income inequality, at least at low levels of income, translates into even higher inequality in carbon emissions. From these observations it may be inferred that that an emerging middle class, at

embodied in trade should not be interpreted as a sign of 'outsourcing' of emissions, as a solid assessment of developed countries' responsibility for rising emissions in developing countries would require an assessment of a counterfactual situation (i.e. what these emissions would be without trade; see Jakob and Marschinski 2013). 
least in middle income countries, could further drive emission growth if energy systems are not significantly decarbonized.

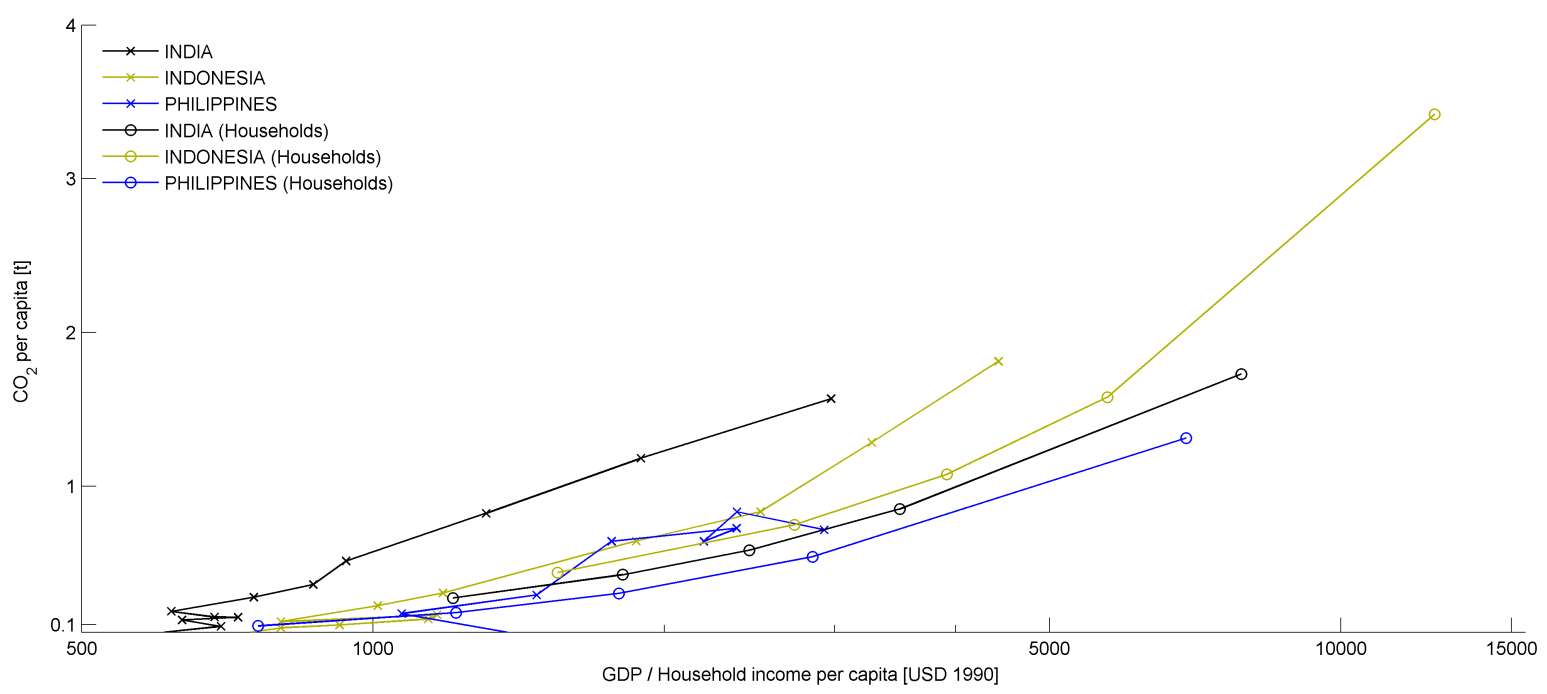

Figure 2: Combined microand macro data for India, Indonesia and the Philippines. For household data income quintiles (with emission for income quintiles shown at their mean income) are shown, derived from Grunewald et al. (2012a) for India, Serino (2012) for Indonesia and Irfany (2013) for the Philippines. Macro economic data are taken from CDIAC (2013) for CO2 per capita and Maddison (2010) for GDP per capita data showing data points for every 10 years from 1900 to 2008 when available.

However, empirical studies also suggest that at higher levels of income, per capita emissions increase less than proportionally with per capita income (Serino, 2012; Irfany, 2013). That is, threshold effects, for example ownership of energy-intensive consumption goods including refrigerators, airconditioners or cars at some income threshold, are likely to be present. Then, high-inequality countries are not necessarily high per capita emitters; i.e., the aggregate relationship between income inequality, measured for example by the Gini index, and GHG emissions is ambiguous. Using aggregate panel data, Grunewald et al. (2012b) show that, on average, lower inequality is associated with higher per capita emissions, as displayed in Figure 3. This result may be driven by a 'middle class effect'; with people with mid-range incomes improving their income situation, thereby making the income distribution more equal, average per capita emissions also increase. This 'emissionsincreasing effect of lower inequality' is smaller in richer countries (and even reversed for the highest income quintile). 


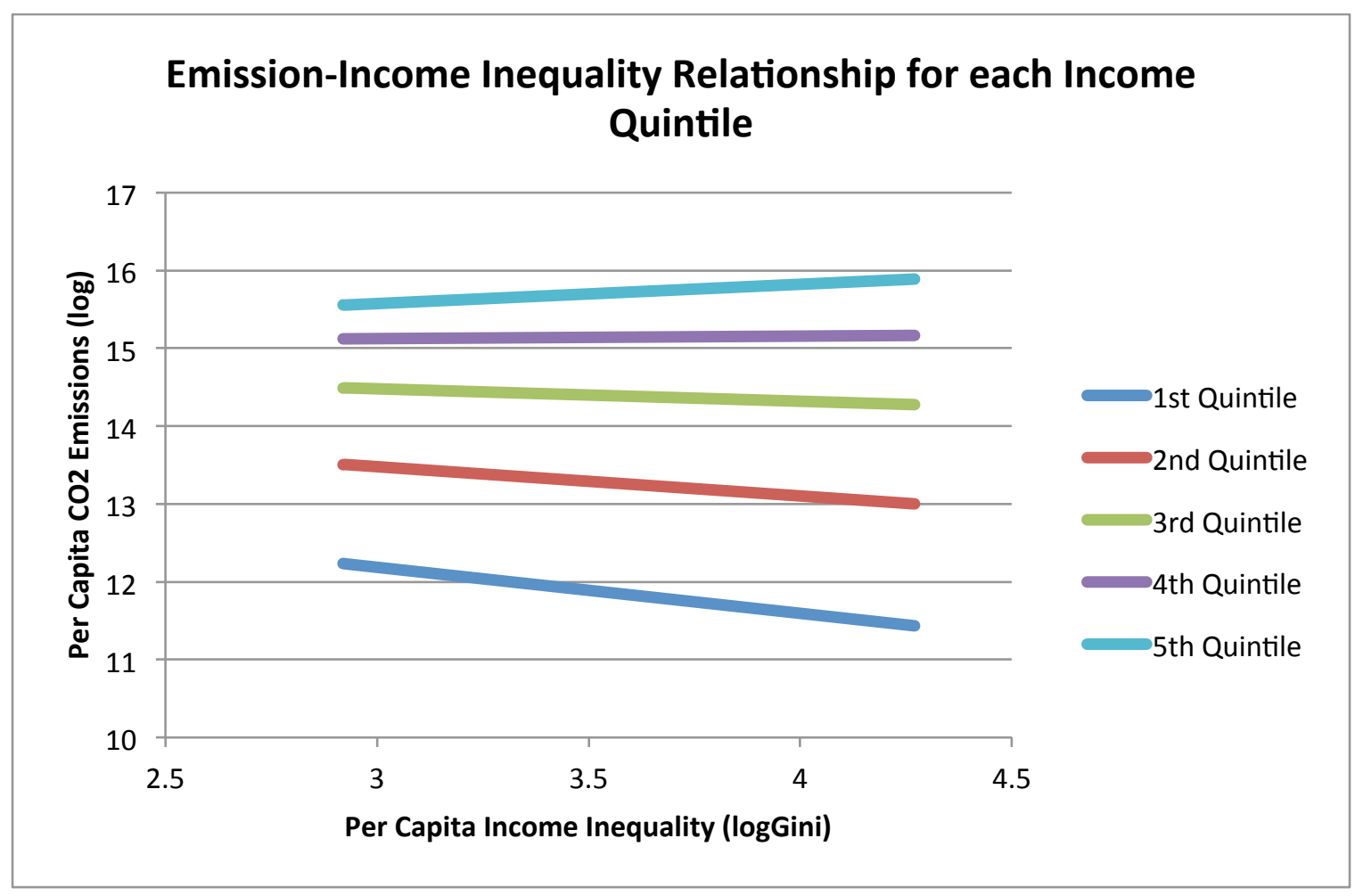

Figure 3: Relationship between income inequality (measured by the natural logarithm of the Gini index (on a scale from 0 to 100; $x$-axis) and the natural logarithm of per-capita CO2 emissions (in kilograms; y-axis) by income quintile. Source: Grunewald et al. (2012a)

Taken together, the above evidence suggests that developing and emerging countries are unlikely to decarbonize their development paths anytime soon. Instead, it looks more likely that per-capita emissions will only stabilize or decline at comparatively high income levels. Such a scenario is corrobated by the finding that the carbon footprints of rich households in developing countries already resemble those of average households in the developed countries. These observations have three immediate implications. First, only a drastic transformation of the global energy system towards low-emission energy sources (such as renewable energy, carbon capture and sequestration, or nuclear) could help change this situation; second, poor and emerging economies would need substantial financial support to cover the incremental costs of low carbon development paths (Collier and Venables, 2012); third, the pattern of within-country differences in income and consumption levels and carbon footprints has an important bearing on the emissions intensity of economic growth and, hence, on policies that may be able to reconcile social and GHG reduction objectives. These issues are taken up below.

\section{Challenges to energy system transformation in developing and emerging countries}

\section{a. Feasibility of emission reductions}

Given the strong link between energy consumption and development in the past, it needs to be expected that future growth of today's poor countries will require a large amount of additional energy. Steckel et al. (2013) show that mitigation scenarios implicitly assume that developing 
countries will not significantly increase their current levels of energy use in climate change mitigation scenarios. In the light of the results described in Section II, reducing energy consumption below a particular threshold does not seem to be a feasible option, as energy will be required for basic needs, infrastructure and other consumption goods demanded by a growing middle class in today's developing countries (Ekholm et al. 2010). At the same time, developing countries are expected to perform a large and rising share of global mitigation. That is, in ambitious mitigation scenarios (IPCC category I + II, ref), the median share of emission reductions (compared to the business-as-usual scenario) taking place in developing (non-Annex I) countries is more than $60 \%$ in the near term and more than $70 \%$ at the end of the century as shown by Figure 4 .

a) Medium ambitious mitigation scenarios (IPCC category III + IV)

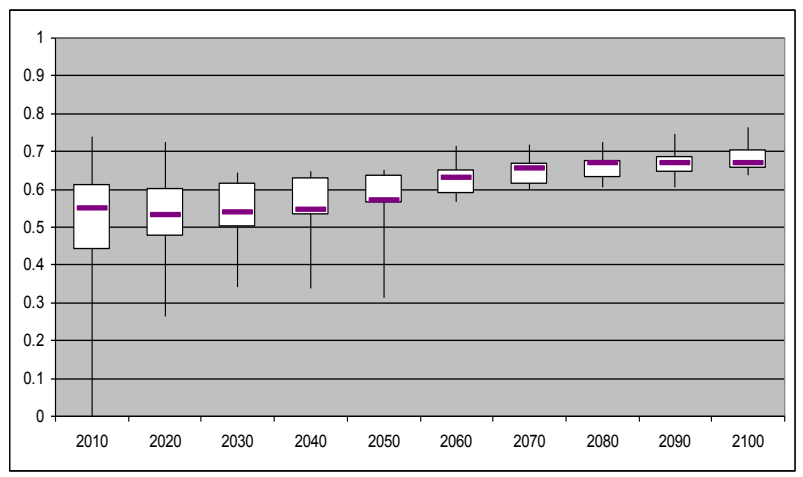

b) Ambitious mitigation scenarios (IPCC category I + II)

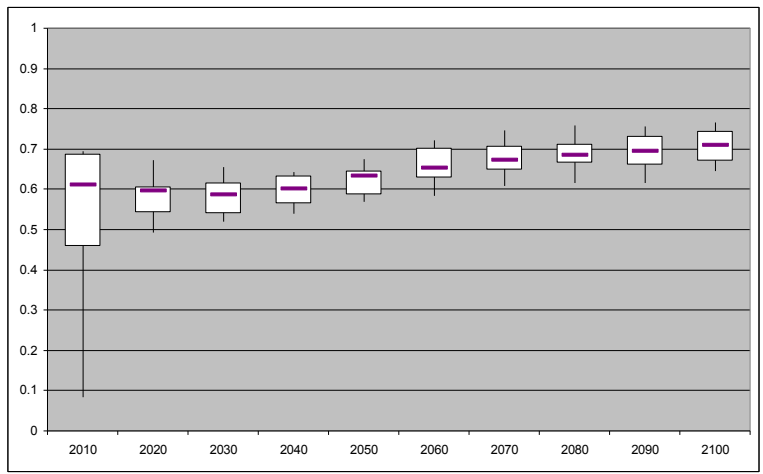

Figure 4: Percentage of global mitigation carried out by non-Annex I countries in differently ambitious climate mitigation scenarios compared to scenarios without climate mitigation in scenarios calculated for the ADAM (Edenhofer et al., 2010) and RECIPE (Luderer et al. 2012) model inter-comparison excercises. Boxes show the 25 - 75 percentile ranges, whiskers the maxima and minima and the bold lines show the median.

Large scale adoption of low-carbon energy sources (RE, nuclear energy, CCS) could permit to increase energy use without at the same time increasing emissions. In particular renewable energy is seen to be key in energy system transformations, shown to have the highest option value of low carbon energy technologies, i.e. forgoing an expansion of RE would result in a more pronounced increase in abatement costs than forgoing the expansion of other technology options (Luderer et al. 2012). Today, renewable energy accounts for only about $11 \%$ of energy use in developing countries of which the largest share is traditional biomass and hydro power (Pfeiffer et al. in press). While the potential for renewable energy is usually seen to be large, it is often still more expensive than fossil fuels (IPCC 2011). Additional obstacles including lacking institutional capacities and credit constraints also hinder the transformation of the energy system on a larger scale (Staub-Kaminski et al. in press, Collier and Venables 2012).

On the micro energy level, renewable energy technologies are often competitive today (Casillas and Kammen 2010) and can contribute to fulfilling basic needs. However, such decarbonization of energy systems is linked to very high incomes. A recent analysis of Kenyan households' lighting fuel choices, which suggests that while there is a cross-sectional energy ladder, the income threshold for modern fuel use - including solar energy use - is very high (Lay et al. 2012). Furthermore, scaling up low carbon energy-supply to a level needed beyond fulfilling basic needs is rather difficult and would probably impose additional costs on developing countries (Jakob and Steckel 2013). This implies that much more action and support (including finances, technologies, and capacity-building) will be 
required to promote renewable energies in developing counties. Due to persistent energy shortages, legitimate energy access targets, and high economic growth, the cost of waiting until such support materializes, is high (Collier and Venables, 2012), necessitating fast concerted action in order to avoid lock-in effects that would make a reorientation of energy systems more difficult and costly in future (Jakob et al. 2012a).

\section{b. A climate rent curse?}

It is widely acknowledged that developing countries should not be negatively influenced by climate change mitigation, as e.g. reflected in the UNFCCC principle of 'common but differentiated responsibilities' (Mattoo and Subramanian 2010). As a consequence, scenarios frequently assume that mitigation efforts are shared globally according to an equitable allocation scheme (e.g. emission certificates being allocated according to an equal per capita scheme). Studying the effects of such schemes generally leads to mitigation for developing countries being feasible at acceptable costs or even gains (Luderer et al. 2012) due to sizable financial transfers from developed regions; thus these transfers should help overcome financial and institutional barriers for low-carbon development. ${ }^{2}$ Jakob et al. (2012c) estimate these financial transfers could - at least for those allocation schemes that are usually perceived to be the most equitable - reach almost USD $400 \mathrm{bln}$ in 2020 and for some regions be of a comparable order of magnitude as revenues from natural resource exports in the past.

Such sizable transfers, however, might negatively affect long term growth prospects, comparable to adverse effects observed for natural resource revenues (Sachs and Warner 1995, Nordhaus 2007) and foreign aid (Djankov et al. 2008). The literature (see van der Ploeg 2011 for a detailed review) has identified several channels to drive this so-called 'resource curse', of which Dutch Disease, volatility, and rent seeking in combination with the quality of the institutional environment are most important. Analyzing similarities between those channels, Kornek et al. (2013) conclude that financial transfers for climate change mitigation could generally be comparable to resource revenues and hence have the potential to result in a 'climate rent curse', in particular for countries with weak institutions. Figure 5 shows indicators for 'rule of law' and 'control of corruption' exemplarily for institutional quality, ranging from -2.5 to 2.5 (WGI, 2013) for countries that would have received transfers if an 'equal per capita' allocation scheme had been in place in $2008^{3}$. Countries are ranked according to the share of the inflows in GDP. Countries that receive the highest transfers generally also score relatively badly (i.e. below 0) on institutional quality. In particular, with very few exceptions, countries that receive more than median financial inflows display institutional quality below the median (i.e. the upper right quadrant is practically empty). As institutional quality is often perceived as crucial for absorbing financial inflows (Kornek et al. 2013, looking at selected countries), Figure 5 suggests that most of the countries receiving the highest inflows might indeed be at risk of suffering from a 'climate finance curse'. In addition, while financial transfersare usually perceived to result in higher degrees of participation in international climate agreements (e.g. Altamirano-

\footnotetext{
${ }^{2}$ Propositions to establish a global carbon budget (WBGU, 2009,) similarly imply considerable financial transfers, mostly for countries at an early stage of development.

${ }^{3}$ Here, we assume per capita emission rights of two tons; note that we only consider energy-related emissions.
} 
Cabrera and Finus 2006, Weikard 2009), international cooperation could be significantly impeded when taking into account potential negative effects of financial inflows from climate finance (Kornek et al. 2013).

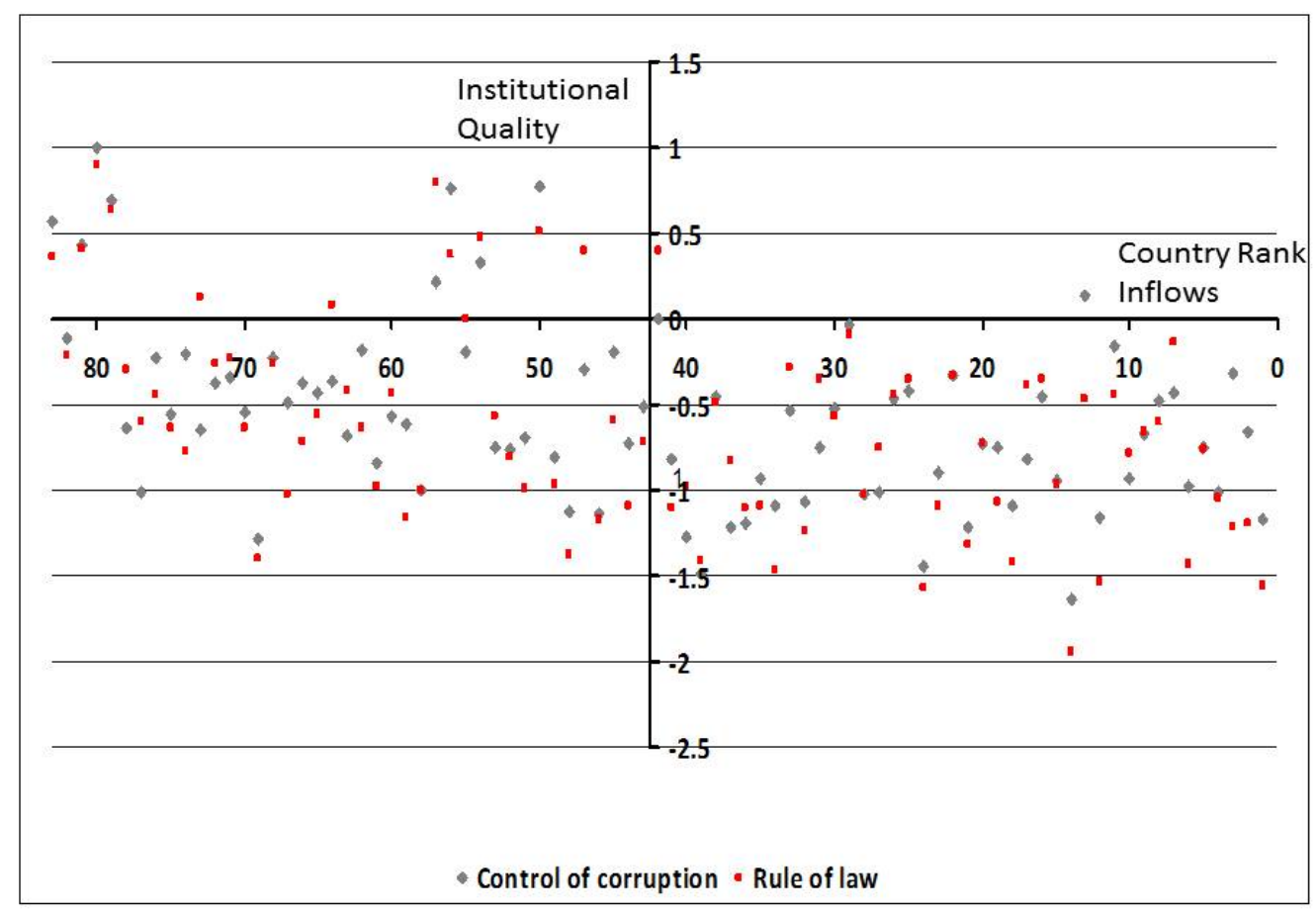

Figure 5: Indicators for 'control of corruption' and 'rule of law' ranging from -2.5 for very low to 2.5 for very high institutional quality (Source: WGI 2013) over countries with per capita emissions of lower than $2 t$ in the year 2008, i.e. those would have received transfers if an international carbon market based on an 'equal per capita' allocation had been in place in 2008 (Based on data from WDI 2013). Countries are ranked based on the financial inflows' share in GDP independent of a potential carbon price.

\section{c. Income Distribution and Political Economy Issues}

The relationship between household incomes and emissions discussed in Section II suggests that countries in certain phases of economic development may face a trade-off: While income growth for lower and middle income classes, and hence lower inequality, is desirable for many reasons (see Klasen 2008), such income growth pattern may lead to higher per-capita emissions, mainly because of increased modern carbon-intensive energy use. For rich countries, (including most current industrialized countries), on the other hand, lower inequality would be associated with lower per capita emissions so that there is clear evidence of a win-win situation. As a consequence, the high carbon footprint of rich(er) households in developing countries would offer pathways to reduce emissions while simultaneously addressing income inequality through well-designed price and tax policies. However, rising growth and prosperity in developing countries has in many countries been accompanied by a policy environment that actually promotes carbon intensive lifestyles. A prominent example are fossil fuel subsidies. Besides their negative effects on the environment and local air pollution, they create substantial externalities such as congestion and impose high costs on 
state budgets. For instance, in 2011 the Iran spent roughly USD 65 bln on subsidizing energy consumption, India about USD 34 bln and China about USD 20 bln (IEA and OECD 2013). Despite their adverse impacts, fuel subsidies of different kinds are still a common policy instrument throughout the developing world. This is likely explained by political economy arguments, with powerful interest groups blocking subsidy reforms that might result in more efficient energy use and have progressive distributional impacts, while at the same time reducing $\mathrm{CO}_{2}$ emissions (Sterner et al. 2011, Rao 2012).

\section{Conclusions: A step-wise approach for low-carbon development}

Our analysis points to a major dilemma for global climate policy: While mitigation of GHG emissions in developing countries will be essential in any effort to limit global warming, economic growth is closely related to energy use, and spontaneous leap-frogging to less energy-intensive development paths seems highly unlikely. Yet, requiring developing countries to forgo economic growth and putting their development goals at risk is clearly not defensible from an ethical perspective.

Concerns about foregone growth opportunities are probably the fundamental explanation why a globally binding climate agreement is very unlikely to materialize in the near future. Yet, several nonAnnex I countries, including China, Mexico, South Korea and Vietnam have recently announced unilateral emission targets and the creation of emission trading systems (Townshend et al. 2013). According to Ostrom (2010), these developments are at odds with conventional collective action theory that would predict free-riding incentives to undermine the implementation of effective climate policies (Carraro and Siniscalco, 1993, Barrett, 1994). In reality, however, policy makers usually pursue multiple objectives, some of which may be related to climate policies. Therefore, a 'polycentric' perspective could identify incentives for actors on different governance levels to adopt policies with objectives that are not related to climate change, but that still mitigate GHG emissions as a co-benefit. Such policies may form the core of 'feasible mitigation actions' for developing countries. For instance, policies aimed at improving public transport and energy access may primarily be implemented from a development perspective, but may nevertheless offer significant emissions reduction potentials (Creutzig and He 2009). Environmental regulation may not only bring about important health co-benefits (Nemet et al. 2010), but also result in higher energy-efficiency (Zimmer et al. 2013). Off-grid solutions are economically viable solutions to provide electricity to very remote rural locations and they typically use low carbon energy sources (Casillas and Kammen 2010, Doll and Pachauri 2010). In some countries, energy security considerations may drive energy system transformation (Dubash 2013).

Voluntary national or regional policies adopted by some first movers could in the future evolve into a global system of loosely coordinated climate agreements that provide flexibility with regard to structures and enforcement mechanisms (Barrett and Toman 2010). For instance, it is conceivable that emerging emission trading systems in developing countries could be linked to those in industrialized regions (for instance the EU ETS or Australia's planned emission trading system) by allowing trading of emission permits between systems. In the longer term, such 'small steps' could promote technological innovation and change the political landscape to pave the way towards a gradual expansion (Urpelainen 2013) and finally a (at least almost) global carbon market (Flachsland et al. 2009). An additional multi-level governance approach to incentivize emission reductions consists in the formation of regional integration agreements (RTAs) that go beyond trade 
liberalization and include inter alia environmental provisions. Recent studies have found empirical evidence such RTAs reduce absolute pollution levels (Bagdadiet al. 2013)

The systematic identification of all the above options, whose mix will obviously differ considerably between countries, should be closely aligned with the process of formulating'nationally appropriate mitigation actions' (NAMAs, see UNFCCC 2009). This process would also clarify the assistance and possibly associated financial requirements that could partly be covered by the Green Climate Fund and bi- and multi-lateral donors, such as the World Bank or the GEF. In addition, donors have already begun to mainstream climate change into their aid portfolios, which should give some impetus to reducing emissions in areas not primarily targeted at climate change mitigation.

In summary, even without global action to reduce emissions, multiple options to promote mitigation in developing countries exist. However, such a piecemeal approach that relies on 'low hanging fruits' will probably lead to considerably slower progress than expected under optimistic mitigation scenarios. This approach will not be cost efficient at a global scale and is very likely to render ambitious climate targets more costly or even infeasible to achieve. However, the piecemeal improvements and the implied sub-optimal global emission trajectory may, at least to some extent, avoid lock-in into carbon-intensive infrastructure, keep the option of more ambitious future mitigation open and pave the way towards a global climate agreement. 


\section{References}

Altamirano-Cabrera, J.-C. and Finus, M. (2006): Permit trading and stability of international climate agreements, Journal of Applied Economics, Vol. 9(1), pp. 19-48

Barrett, S. (1994). Self-enforcing international environmental agreements. Oxford Economic Papers, 878-894.

Barrett, S. and Toman, M. (2010): Contrasting Future Paths For An Evolving Global Climate Regime, World Bank Policy Research Working Paper 5164

Carraro, C., \& Siniscalco, D. (1993): Strategies for the international protection of the environment. Journal of Public Economics, 52(3): 309-328.

Casillas, C. E., \& Kammen, D. M. (2011). The delivery of low-cost, low-carbon rural energy services. Energy Policy, 39(8), 4520-4528

CDIAC (2013): Carbon Dioxide Information Analysis Centre, http://cdiac.ornl.gov/ (accessed 14 September 2013)

Collier, P. and Venables, A. (2012): Greening Africa? Technologies, endowments and the latecomer effect, Energy Economics 34(S1): S75-S84.

Costa L, Rybski D, Kropp JP (2011): A Human Development Framework for CO2 Reductions. PLoS ONE 6(12): e29262. doi:10.1371/journal.pone.0029262

Creutzig, F. and He, D. (2009) Climate change mitigation and co-benefits of feasible transport demand policies in Beijing. Transportation Research D 14: 120-131

Davis, S.J. and K. Caldeira (2010). Consumption-Based Accounting of CO2 Emissions. Proceedings of the National Academy of Sciences of the U.S.A., 107 (12):5687-5692.

Djankov, S., Montalvo, J. G., \&Reynal-Querol, M. (2008). The curse of aid. Journal of Economic Growth, 13(3), 169-194.

Doll, C. N.H. and Pachauri, S. (2010): Estimating rural populations without access to electricity in developing countries through night-time light satellite imagery, Energy Policy 38(10): 5661-5670

Dubash, N-K. (2013): The politics of climate change in India: narratives of equity and cobenefits. Wiley Interdisciplinary Reviews: Climate Change 4(3): 191-201

Edenhofer, O., Knopf, B., Barker, T., Baumstark, L., Bellevrat, E., Chateau, B., Criqui, P., Isaac, M., Kitous, A., Kypreos, S., Leimbach, M., Lessmann, K., Magné, B., Scrieciu, S., Turton, H., van Vuuren, D.P. (2010): The Economics of Low Stabilisation: Model Comparison of Mitigation Strategies and Costs. The Energy Journal, Volume 31 (Special Issue 1). The Economics of Low Stabilization, pp. 11-48

Ekholm, T. Krey, V., Pachauri, S., Riahi, K., (2010): Determinants of household energy consumption in India, Energy Policy, 38(10): 5696-5707

Flachsland, C., R. Marschinski, and O. Edenhofer. Global trading versus linking: Architectures for international emissions trading. Energy Policy 2009, 38: 4363-4370 
Grübler, A. Energy transitions. In: Cleveland, C.J. (Ed.), Encyclopedia of Earth. Environmental Information Coalition, National Council for Science and the Environment, 2008

Grunewald, N., Harteisen, M., Lay, J., Minx, J., Renner, S. (2012a): The Carbon Footprint of Indian Households, paper presented at the IARIW Boston.

Grunewald, N., Klasen, S., Martínez-Zarzoso, I., Muris, C. (2012b): Income inequality and carbon emissions, submitted

IEA (2011): World Energy Outlook. Paris.

IPCC (2011) Special Report on Renewable Energy Sources and Climate Change Mitigation. Prepared by Working Group III of the Intergovernmental Panel on Climate Change [O. Edenhofer, R. PichsMadruga, Y. Sokona, K. Seyboth, P. Matschoss, S. Kadner, T. Zwickel, P. Eickemeier, G. Hansen, S. Schlömer, C. von Stechow (eds)]. Cambridge University Press, Cambridge and New York

Irfany, M.I. (2012): De-carbonization and Development Paths: Analysis of Indonesian Household Carbon Footprint

Jaeger, C.C. and Jaeger, J. (2011): Three views of two degrees, Regional Environmental Change 11, pp. 15-26

Jakob, M, and Marschinski, R. (2013). Interpreting Trade-Related CO2 Emission Transfers. Nature Climate Change 3 (1), p.19-23

Jakob, M. and JC Steckel (2013): How climate change mitigation could harm development in poor countries. Working paper: 1-12

Jakob, M., G. Luderer, J. Steckel, M. Tavoni, S. Monjon (2012a): Time to act now? Assessing the costs of delaying climate measures and benefits of early action. Climatic Change 114(1): 79-99

Jakob, M., Haller, M., \& Marschinski, R. (2012b): Will history repeat itself? Economic convergence and convergence in energy use patterns. Energy Economics, 34(1): 95-104.

Jakob, M., JC Steckel, C. Flachsland, and L. Baumstark (2012c): Climate finance for developing country mitigation: Blessing or curse? Working Paper: $1-29$

Klasen, S. (2008) "The efficiency of equity". Review of Political Economy 20: 257-274. (2008).

Kornek, U., JC Steckel, K. Lessmann and O. Edenhofer. The climate rent curse: New challenges for burden sharing. Working Paper , 2013: 1- 41

Lay, J., Ondraczek, J, Stoever, J. (forthcoming). Determinants of renewable energy use: Solar home systems and lighting fuel choice in Kenya. Energy Economics

Luderer, G., Bosetti, V., Jakob, M., Leimbach, M., Steckel, J. C., Waisman, H., \& Edenhofer, O. (2012): The economics of decarbonizing the energy system-results and insights from the RECIPE model intercomparison. Climatic Change 2012, 114: 1-29.

Mattoo, A. and Subramanian, A. (2012): Equity in Climate Change: An Analytical Review, World Development, 40(6): 1083-1097 
Nemet, G.F., Holloway, T., Meier, P. (2010): Implications of incorporating air-quality co-benefits into climate change policymaking, Environmental Research Letters 5 (014007)

Nordhaus, William D. To tax or not to tax: Alternative approaches to slowing global warming. Review of Environmental Economics and Policy 2007, 1 (1): 26-44.

OECD and IEA (2013): Fossil Fuel subsidies and other support, http://www.oecd.org/site/tadffss/ (accessed 5 September 2013)

Olivier, J.G.J., Janssens-Maenhout, G., Peters, J.A.H.W. (2012): Trends in global $\mathrm{CO}_{2}$ emissions. 2012 Report, http://edgar.jrc.ec.europa.eu/CO2REPORT2012.pdf (accessed 14 September 2013)

Ostrom, E. (2010): Polycentric systems for coping with collective action and global environmental change. Global Environmental Change, 20: $550-557$

Pereira, M. G., Sena, J. A., Freitas, M. A. V., \& da Silva, N. F. Evaluation of the impact of access to electricity: A comparative analysis of South Africa, China, India and Brazil. Renewable and Sustainable Energy Reviews 2011, 15(3), 1427-1441.

Peters, G., Minx, J. Weber, C. L. \& Edenhofer, O. Growth in emission transfers via international trade from 1990 to 2008. Proc. Natl Acad. Sci. 108, 8903-8908 (2011).

Pfeiffer, B., Mulder, P. (in press). Explaining Renewable Energy Technology Diffusion in Developing Countries, Energy Economics

Rao, N.D. Kerosene subsidies in India: When energy policy fails as social policy. Energy for Sustainable Development 2012, 16(1): 35-43

Sachs, J.D. and A.M. Warner. Natural resource abundance and economic growth. Natural Bureau of Economic Research, Working Paper, 1995

Schäfer, A. Structural change in energy use. Energy Policy 2005, 33: $429-437$

Seriño (2012): Do Philippine Households Lead a Carbon Intensive Lifestyle?

Staub-Kaminski, I. , A. Zimmer, M. Jakob and R. Marschinski (in press): Putting Climate Policy into Practice: A Typology of Obstacles and Implications for Integrated Assessment Modeling, Climate Change Economics

Steckel, JC, M. Jakob, R. Marschinski, G. Luderer (2011): From carbonization to decarbonization? Past trends and future scenarios for China's CO2 emissions. Energy Policy, 39 (6): $3443-3455$

Steckel, JC, RJ Brecha, M. Jakob, J. Strefler, G. Luderer. Development without energy? Assessing future scenarios of energy consumption in developing countries. Ecological Economics 2013, 90: $53-$ 67

Steinberger, J. and JT Roberts. From constraint to sufficiency: The decoupling of energy and carbon from human needs 1975 - 2005. Ecological Economics 2010, 70: 425 - 433

Sterner, T., ed. (2011). Fuel Taxes and the Poor: The Distributional Effects of GasolineTaxation and Their Implications for Climate Policy. Washington, D.C.: Resourcesfor the Future (RFF) Press. 
Townsend, T., S. Fankhauser, S. Aybar, M. Collins, T. Landesman, M. Nachmany, C. Pavese (2013): The GLOBE Climate Legislation Study. 3rd edition. A review of climate change legislation in 33 countries.

UNFCCC (1992): United Nations Framework Convention on Climate Change.

UNFCCC (2009): Decision 2/CP.15, Copenhagen Accord, December 7-19 2009, http://unfccc.int/resource/docs/2009/cop15/eng/I07.pdf (accessed 14 September 2013).

Urpelainen, J: (2013): A model of dynamic climate governance: dream big, win small, International Environmental Agreements: Politics, Law and Economics, 13(2): 107-125

Van der Ploeg, F. Natural resources: Curse or blessing? Journal of Economic Literature 2011, 49(2): 366-420

WBGU (2009): Solving the Climate Dilemma - the Budget Approach. German Advisory Council on Global Change (WBGU)

WDI (2013): World Development Indicators, http://databank.worldbank.org/data/views/variableSelection/selectvariables.aspx?source=worlddevelopment-indicators (accessed 20 August 2013)

Weikard, H.-P. (2009): Cartel Stability Under An Optimal Sharing Rule, Manchester School, Vol. 77(5), pp. 575-593.

WGI (2013): Worldwide Governance Indicators, http://info.worldbank.org/governance/wgi/ (accessed 20 August 2013)

World Bank (2010): World Development Report. Washington D.C.

Zimmer, A., Jakob, M., Steckel, J. (2013): What motivates Vietnam to strive for a low-carbon economy? An explorative case study on the drivers of climate policy in a developing country, Working Paper 